\title{
Effect of amino acid supplementation and choline chloride for low protein diet on nitrogen efficiency and methane emission of dairy cows
}

\section{Efeito da suplementação de aminoácidos e cloreto de colina para dieta pobre em proteínas na eficiência de nitrogênio e emissão de metano de vacas leiteiras}

\author{
Shahram Shirmohammadi'; Akbar Taghizadeh ${ }^{1 *}$; Ali Hosseinkhani1; Hossein \\ Janmohammadi ${ }^{1}$; Rasoul Pirmohammadi ${ }^{2}$; Hadi Valizadeh ${ }^{3}$
}

\section{Highlights}

$\mathrm{N}$ excretion, retention and $\mathrm{CH}_{4}$ emission from dairy farms are major nutritional facts.

Dietary $\mathrm{N}$ utilization exceled by rumen protected amino acids.

Ruminal and excreta parameters along with $\mathrm{CH}_{4}$ emission were evaluated.

Environment and animal performance preserved by rumen protected amino acids.

\begin{abstract}
Ruminants are one of the largest anthropogenic methane and nitrous oxide emissions. Therefore, the hypothesis was to study the effects of reducing dietary crude protein (CP) level on environmental contaminators when rumen-protected amino acids and choline chloride were supplemented. Sixty Holstein dairy cows were used during the experiment. Test diets were: (1) CD = Control diet with $16.2 \mathrm{~g}$ of crude protein/ $\mathrm{Kg}$ of DM); (2) $\mathrm{LM}=$ Low protein diet with $14.2 \mathrm{~g}$ of crude protein/ $\mathrm{Kg}$ of DM + methionine ; (3) LL = Low protein diet with $14.2 \mathrm{~g}$ of crude protein/ Kg of DM + lysine; (4) LML = Low protein diet with $14.2 \mathrm{~g}$ of crude protein/ $\mathrm{Kg}$ of DM + methionine + lysine; (5) LMLC = Low protein diet with $14.2 \mathrm{~g}$ of crude protein/ $\mathrm{Kg}$ of DM + methionine + lysine + choline. Dry matter and NDF intake were not different, but the control group received higher CP and ADF compared with other groups $(P<0.05)$. Fecal $C P$ and ADF of control group were lower $(P<0.05)$, but no differences were observed for fecal dry matter (DM) and NDF. Milk yield and protein content were higher for LML and LMLC like control group $(P<0.05)$. Nitrogen intake, urinary $N$, urinary urea $N$ and total excreta $\mathrm{N}$ decreased $(\mathrm{P}<0.05)$ when animals fed low protein. There was no difference in ruminal $\mathrm{pH}$ and acetate to

1 Students of Doctorial Course, Profs. Drs. of Department of Animal Sciences, Faculty of Agriculture, University of Tabriz, Tabriz, Iran. E-mail: sh.mohammadi@tabrizu.ac.ir; a_tagizadeh@tabrizu.ac.ir; A.hosseinkhani@tabrizu.ac.ir; janmohammadi@tabrizu.ac.ir

2 Department of Animal Science, Faculty of Agriculture, Urmia University, Urmia, Iran. E-mail: r.pirmohammadi@urmia. ac.ir

${ }^{3}$ Department of Pharmaceutics, Faculty of Pharmacy, Tabriz University of Medical Sciences, Tabriz, Iran. E-mail: valizadeh@tbzmed.ac.ir

* Author for correspondence
\end{abstract}

Received: June 22, 2021 - Approved: Oct. 08, 2021 
propionate ratio, whereas the ruminal ammonia- $\mathrm{N}$ decreased with the low protein $(\mathrm{P}<0.05)$. The $120-\mathrm{h}$ gas production test, showed no difference on the kinetics of digestion and in vitro methane emission. However, the inclusion of DMI in the calculations revealed that low protein can reduce $(P<0.05)$ methane emission. Overall, our findings indicated that low protein can be compensated for by adding rumen-protected amino acids, not only to maintain the animal performance, but also to decrease nitrogen excretion and methane emission.

Key words: Crude protein. Environmental. Gas production. Methane. Nitrogen retention. Ruminants.

\section{Resumo}

Os ruminantes são uma das maiores emissões antropogênicas de metano e óxido nitroso. Portanto, a hipótese foi estudar os efeitos da redução do nível de proteína bruta (PB) na dieta sobre os contaminantes ambientais quando aminoácidos protegidos no rúmen e cloreto de colina foram suplementados. Sessenta vacas leiteiras Holstein foram utilizadas durante o experimento. As dietas teste foram: (1) CD = dieta controle com $16.2 \mathrm{~g}$ de proteína bruta / Kg de MS); (2) LM = Dieta pobre em proteínas com $14.2 \mathrm{~g}$ de proteína bruta / Kg de DM + metionina; (3) LL = Dieta pobre em proteínas com $14.2 \mathrm{~g}$ de proteína bruta / Kg de MS + lisina; (4) $\mathrm{LML}$ = Dieta pobre em proteínas com $14.2 \mathrm{~g}$ de proteína bruta / Kg de DM + metionina + lisina; (5) LMLC = Dieta pobre em proteínas com $14.2 \mathrm{~g}$ de proteína bruta / Kg de DM + metionina + lisina + colina. O consumo de matéria seca e FDN não foi diferente, mas o grupo controle recebeu maior PB e FDA em comparação com os outros grupos $(P<0.05)$. A PB e FDA fecal do grupo controle foram menores $(P<0.05)$, mas não foram observadas diferenças para matéria seca (MS) e FDN fecal. A produção de leite e o teor de proteína foram maiores para $L M L$ e LMLC como grupo controle $(P<0.05)$. A ingestão de nitrogênio, $N$ urinário, $N$ urinário urinário e $\mathrm{N}$ excreta total diminuíram $(\mathrm{P}<0.05)$ quando os animais foram alimentados com baixa proteína. Não houve diferença no $\mathrm{pH}$ ruminal e na relação acetato / propionato, enquanto o $\mathrm{N}$-amônia ruminal diminuiu com o baixo teor de proteína $(P<0.05)$. $O$ teste de produção de gás de 120 h, não mostrou diferença na cinética de digestão e emissão de metano in vitro. No entanto, a inclusão do CMS nos cálculos revelou que a baixa proteína pode reduzir $(P<0.05)$ a emissão de metano. No geral, nossos resultados indicaram que o baixo teor de proteína pode ser compensado pela adição de aminoácidos protegidos no rúmen, não apenas para manter o desempenho animal, mas também para diminuir a excreção de nitrogênio e a emissão de metano.

Palavras-chave: Proteína bruta. Ambiental. Produção de gás. Metano. Retenção de nitrogênio. Ruminantes.

\section{Introduction}

Ruminants produce meat and milk, by converting human-indigestible plant into human edible food products via adaptation of the ruminal digestive tract microbiome (Van Zanten, Meerburg, Bikker, Herrero, \& De Boer, 2016). On the other hand, ruminants are one of the pollutant sources (Greening et al., 2019). Nowadays the studies are concentrating on decreasing of level of protein in dairy cow diets, because low protein in the diets can set low excreta of nitrogen $(\mathrm{N})$. One of the most useful strategies is to reduce dietary crude protein (CP) level to reduce $\mathrm{N}$ excretion through urine and manure (Lee et al., 2012b). However, reducing CP level can decrease metabolizable protein supply to less than minimum requirements (National Research Council [NRC], 2001), which can reduce 
animal efficiency (Lee et al., 2011). Yet adding individual amino acids (aa) to metabolizable protein supply may compensate cow productivity. Methionine and lysine have been suggested as the first-limiting amino acids on corn-based diets (NRC, 2001). Thus, adding rumen-protected (RP) DL-methionine (RPMet) and choline (RPChol) as methyl donors and rumen-protected L-lysine (RPLys) may improve dairy cow efficiency along with decreased level of $\mathrm{N}$ excreta to the environment (Swanepoel, Robinson, \& Erasmus, 2010; Giallongo et al., 2016; Zenobi et al., 2018). However, some studies implied protein sources containing of rumen undegradable protein (RUP) are improving dairy cow performance (Amanlou, Farahani, \& Farsuni, 2017; Rehman et al., 2020), but in most studies applying of essential amino acids supplementing showed high efficiency in nitrogen retention (Noftsger, St-Pierre, \& Sylvester, 2005; Gomez et al., 2011; Lee et al., 2012a; Lee et al., 2012b). Beside N excretion, methane production by ruminal methanogens seems important.

\section{Dominant} Methanobrevibacter Methanobrevibacter the most dominant rumen methanogens (about $74 \%$ of the biomass), utilize molecular hydrogen $\left(\mathrm{H}_{2}\right)$ for reducing carbon dioxide $\left(\mathrm{CO}_{2}\right)$ to methane $\left(\mathrm{CH}_{4}\right)$ (Leahy et al., 2010; Thauer, 2012; Henderson et al., 2015). At the presence of $\mathrm{H}_{2}$ as the basal substrate for ruminal methanogenesis (produced through multiple carbohydrate fermentation pathways) together with the volatile fatty acids (VFA) and $\mathrm{CO}_{2}$ (Seshadri et al., 2018; Solden et al., 2018; Stewart et al., 2018), ruminal methanogens can use acetate, formate, ethanol and methyl compounds as substrates (Kelly et al., 2014; Henderson et al., 2015; Lambie et al., 2015; Li et al., 2016). Along with environmental concerns, it is believed that produced methane in the rumen cause an energy loss of about 2 to $12 \%$ in ruminants metabolizable energy (ME) which could consequently reduce total efficiency of the animal performance (Johnson \& Johnson, 1995; Gill, Smith, \& Wilkinson, 2010; Hynes, Stergiadis, Gordon, \& Yan, 2016; Serrano, Cruz, Coneglian, \& Branco, 2020). Since ruminants contribute in greenhouse gas emission, variety of programs are underway to decrease the methane production (Martin, Morgavi, \& Doreau, 2010; Buddle et al., 2011; Kiggundu, Nantongo, Kayondo, \& Mugerwa, 2019). Todate, direct inhibition of the methanogen bacteria, whether by vaccine and or antimicrobial compounds, was assumed to be the main strategy yet (Wedlock, Janssen, Leahy, Shu, \&Buddle, 2013; Hristovetal., 2015; Weimar et al., 2017; Henderson, Cook, \& Ronimus, 2018) feed or nutritional management could be an alternative policy (Kiggundu et al., 2019). Nutritional management approaches can be used to regulate the supply of methanogen bacteria substrates, like molecular hydrogen and ammonia (Buddle et al., 2011; Wu et al., 2018; Sun, Aguerre, \& Wattiaux, 2019; van Lingen, Jonker, Kebreab, \& Pacheco, 2021).

Ruminal methanobacteria use ammonia to propagate and simultaneously produce microbial protein for the host animal (Jarrell \& Kalmokoff, 1988; NRC, 2001). It is of note that the main source of the ammonia is the rupture of rumen-degradable protein (RDP) (NRC, 2001; Kalscheur, Vi, Glenn, \& Kohn, 2006). To date many approaches have been set by scientists to address greenhouse gas emission reduction strategies of which livestock diet RDP restriction seems to be more practical. Restricting RDP level can influence methane production as well as nitrate excretion ( $\mathrm{NO}_{3}{ }^{-}$) (Sun et al., 2019). 
Thus, the objective of current study was to investigate the effects of low protein diets supplemented with rumen-protected Met, Lys and choline on $\mathrm{N}$ utilization, $\mathrm{N}$ excretion and methane emission in Holstein lactating dairy cows.

\section{Material and Methods}

\section{Animals, treatments and experimental design}

A total number of sixty Holstein dairy cows (30 primiparous and 30 multiparous) were used in a two-phase experiment (each phase was 30 cows; 15 primiparous and 15 multiparous), all cows were treated according to guide to the care and use of experimental animals (I.C.o.A.C. 1995) Cows had body weight of $650 \pm 35 \mathrm{Kg}$ and body condition score $\cong 3$, cows were housed individually in free-stall barns. Every phase was 28 days, first 21 days were for adaptation period and 7 last days considered for sampling. The experiment was conducted in a completely randomized block design, animals of each phase were randomly assigned to one of the five experimental diets, based on their days in milk (DIM), milk yield and parity. Experimental diets, shown in Table 1, were (1) $C D=$ Control diet with16.2 $\mathrm{g}$ of crude protein/ Kg of DM); (2) LM = Low protein diet with $14.2 \mathrm{~g}$ of crude protein/ $\mathrm{Kg}$ of DM + methionine ; (3) LL = Low protein diet with 14.2 $\mathrm{g}$ of crude protein/ Kg of DM + lysine; (4) LML = Low protein diet with $14.2 \mathrm{~g}$ of crude protein/ $\mathrm{Kg}$ of $\mathrm{DM}+$ methionine + lysine; (5) LMLC = Low protein diet with $14.2 \mathrm{~g}$ of crude protein/ $\mathrm{Kg}$ of $\mathrm{DM}+$ methionine + lysine + choline. The diets were formulated to meet the nutrient requirements of cows producing $45 \mathrm{~kg} / \mathrm{d}$ of milk, 3.3\% milk fat and $2.9 \%$ milk true protein except MP requirements (NRC, 2001). The experimental diets were provided as total mixed ration at $07 \mathrm{~h} 30,15 \mathrm{~h} 30$ and $23 \mathrm{~h} 30$, ad libitum for 5 to $10 \%$ of refusals. The RPMet, RPLys and RPChol were fed top-dressed immediately after the diets were delivered. The cows were milked daily at $06 \mathrm{~h} 30,14 \mathrm{~h} 30$ and $22 \mathrm{~h} 30$

Table 1

Ingredient and chemical composition of the experimental diets fed in the trial (\% of DM)

\begin{tabular}{lccccc}
\hline \multirow{2}{*}{ Item } & \multicolumn{5}{c}{ Experimental diets $^{1}$} \\
\cline { 2 - 6 } & Control & LM & LL & LML & LMLC \\
\hline Ingredients, \% of DM & & & & & \\
Corn silage & 20.56 & 20.41 & 20.41 & 20.41 & 20.41 \\
Alfalfa there & 21.49 & 21.33 & 21.33 & 21.33 & 21.33 \\
Wheat straw & 4.08 & 4.05 & 4.05 & 4.05 & 4.05 \\
Cottonseed, whole & 5.06 & 5.02 & 5.02 & 5.02 & 5.02 \\
\hline Beet sugar pulp & 3.73 & 3.71 & 3.71 & 3.71 & 3.71 \\
Molasses & 1.32 & 1.31 & 1.31 & 1.31 & 1.31 \\
Barley grain, ground & 12.79 & 14.33 & 14.33 & 14.33 & 14.33 \\
Corn grain, ground & 12.15 & 13.96 & 13.96 & 13.96 & 13.96 \\
Corn gluten meal & 5.03 & 3.55 & 3.55 & 3.55 & 3.55 \\
Soybean meal (solvent extracted) & 8.23 & 4.49 & 4.49 & 4.49 & 4.49 \\
\hline
\end{tabular}


continuation...

\begin{tabular}{|c|c|c|c|c|c|}
\hline Soybean seeds, whole, heated & 0.82 & 0.82 & 0.82 & 0.82 & 0.82 \\
\hline Corn germ & 0.31 & 0.50 & 0.50 & 0.50 & 0.50 \\
\hline Wheat bran & 0.97 & 2.57 & 2.57 & 2.57 & 2.57 \\
\hline Calcium soap of fatty acids & 0.67 & 1.22 & 1.22 & 1.22 & 1.22 \\
\hline Salt & 0.17 & 0.17 & 0.17 & 0.17 & 0.17 \\
\hline Urea & 0.29 & 0.29 & 0.29 & 0.29 & 0.29 \\
\hline Calcium phosphate (Di) & 0.31 & 0.31 & 0.31 & 0.31 & 0.31 \\
\hline Calcium carbonate & 0.41 & 0.41 & 0.41 & 0.41 & 0.41 \\
\hline Magnesium oxide & 0.17 & 0.17 & 0.17 & 0.17 & 0.17 \\
\hline Sodium bicarbonate & 0.86 & 0.85 & 0.85 & 0.85 & 0.85 \\
\hline Mineral premix ${ }^{2}$ & 0.28 & 0.27 & 0.27 & 0.27 & 0.27 \\
\hline Vitamin premix ${ }^{3}$ & 0.29 & 0.27 & 0.27 & 0.27 & 0.27 \\
\hline Rumen-protected Methionine (RPMet) g/d & - & 30 & - & 30 & 30 \\
\hline Rumen-protected Lysine (RPLys) g/d & - & - & 130 & 130 & 130 \\
\hline Rumen-protected Choline (RPChol) g/d & - & - & - & - & 60 \\
\hline \multicolumn{6}{|l|}{ Composition, \% of DM } \\
\hline $\mathrm{CP}$ & 16.2 & 14.2 & 14.2 & 14.2 & 14.2 \\
\hline RDP & 10 & 9.1 & 9.1 & 9.1 & 9.1 \\
\hline RUP & 6.2 & 5.1 & 5.1 & 5.1 & 5.1 \\
\hline NDF & 32.9 & 32.7 & 32.7 & 32.7 & 32.7 \\
\hline ADF & 24.3 & 24.0 & 24.0 & 24.0 & 24.0 \\
\hline NFC & 41.6 & 43.3 & 43.3 & 43.3 & 43.3 \\
\hline $\mathrm{Ca}$ & 0.8 & 0.9 & 0.9 & 0.9 & 0.9 \\
\hline $\mathrm{P}$ & 0.4 & 0.4 & 0.4 & 0.4 & 0.4 \\
\hline NEL, Mcal/kg & 1.52 & 1.52 & 1.52 & 1.52 & 1.52 \\
\hline NEL balance, Mcal/d & 1.9 & 2.2 & 2.2 & 2.2 & 2.2 \\
\hline \multicolumn{6}{|l|}{ Protein supply, g/d } \\
\hline RDP supply & 2913 & 2667 & 2667 & 2667 & 2667 \\
\hline RDP balance & 116 & -166 & -166 & -166 & -166 \\
\hline RUP supply & 1815 & 1507 & 1507 & 1507 & 1507 \\
\hline RUP balance & 172 & -264 & -264 & -264 & -264 \\
\hline MP supply & 3236 & 2878 & 2878 & 2878 & 2878 \\
\hline MP requirements & 3087 & 3104 & 3104 & 3104 & 3104 \\
\hline MP balance & 149 & -226 & -226 & -226 & -226 \\
\hline Lys/Met & 3.04 & 3.06 & 3.06 & 3.06 & 3.06 \\
\hline
\end{tabular}

${ }^{1}$ Control $=$ diet containing $16.2 \% \mathrm{CP} ; \mathrm{LM}=$ diet containing $14.2 \% \mathrm{CP}$ supplemented with RPMet Mepron [Evonik Nutrition \& Care $\mathrm{GmbH}$, Hanau, Germany]; LL = diet containing 14.2\% CP supplemented with RPLys [Timet; VETAGRO S.p.A.; Reggio Emilia, Italy]; $L M L=$ diet containing $14.2 \%$ CP supplemented with RPLys and RPMet; LMLC= diet containing $14.2 \%$ CP supplemented with RPLys and RPMet and RPChol ReaShure (Balchem Corp., New Hampton, NY).

${ }^{2}$ The premix contained (\%, as-is basis): trace mineral mix, 0.86; $\mathrm{MgO}(56 \% \mathrm{Mg}), 8.0 ; \mathrm{NaCl}, 6.4 ; 0.48$; limestone, 37.2; selenium premix, 0.07; and 46.7. Ca, 14.1\%; $\mathrm{P}, 0.39 \% ; \mathrm{Mg}, 4.59 \% ; \mathrm{K}, 0.44 \% ; \mathrm{S}, 0.39 \% ; \mathrm{Se}, 6.91 \mathrm{mg} / \mathrm{kg} ; \mathrm{Cu}, 362 \mathrm{mg} / \mathrm{kg} ; \mathrm{Zn}$, $1,085 \mathrm{mg} / \mathrm{kg} ; \mathrm{Fe}, 186 \mathrm{mg} / \mathrm{kg}$;

${ }^{3}$ Vitamin ADE premix, vitamin A, 276,717 IU/kg; vitamin D, 75,000 IU/kg; and vitamin E, 1,983 IU/kg. 
Sampling, chemical composition and analyses

Diets and ort were recorded three times a week during the experiment. Individual feed ingredients, TMR and ort were sampled three times a week and composited by week and treatment on equal weight and frozen at $-20^{\circ} \mathrm{C}$ until analyses. Samples were air dried and ground in a Wiley mill. (A. H. Thomas Co., Philadelphia, PA) adjusted to 1-mm sieve, and analyzed for DM (AOAC, 2005); method 930.15), CP (method 984.13), NDF (neutral detergent fiber) and ADF (acid detergent fiber) were determined according to Van Soest, Robertson and Lewis. (1991) using a heatstable $\alpha$-amylase Sigma (Number A3306, Sigma Chemical Co., St. Louis, MO).

\section{Milk and milk composition}

Milk yield was recorded and sampled in three consecutive milking during three days of last experimental week. Samples were composed proportionally according to the production of each milking and added to a 100 $\mathrm{ml}$ falcon tube. The milk samples were analyzed for milk composition using Lactoscan (Milk Analyzer, For Laboratory Use).

\section{Urine and fecal sampling}

Urine samples (about $300 \mathrm{ml}$ per cow) were taken by massaging the vulva. A portable $\mathrm{pH}$ meter was used to measure the $\mathrm{pH}$ immediately after sampling, then acidified to $\mathrm{pH}<3.0$ with $2 \mathrm{M} \mathrm{H}_{2} \mathrm{SO}_{4}$ pre storage at $-20^{\circ} \mathrm{C}$ samples were diluted with distilled water (1:10) for subsequent analyses (Lee et al., 2012b).
Samples of acidified urine were composited according to the cow and treatment, then analyzed for urea N (enzymatic Urease-GLDH method, kit no. 1400030), uric acid (enzymatic colorimetric TOOS method, kit no. 140031) and creatinine (enzymatic Jaffe method, kit no. 1400009) using commercial kits (Pars Azmoon Co., Tehran, Iran) according to the instructions of the manufacture. Daily urine volume was estimated using body weight (BW) and urinary creatinine concentration which was calculated by the equation of 29 (mg/ $\mathrm{kg}) \times \mathrm{BW}(\mathrm{kg}) \times[1 / \mathrm{urinary}$ creatinine $(\mathrm{mg} / \mathrm{L})]$ (Valadares, Broderick, Valadares, \& Clayton, 1999). Fecal samples (approximately $500 \mathrm{~g}$ of each sampling) were collected three times a day (every 8 hours) in three consecutive days of last week. Samples were oven-dried (48 h at $65^{\circ} \mathrm{C}$ ) and then composited by cow and day on equal dry weight basis. The composite samples analyzed for CP, NDF and ADF (Amanlou et al., 2017).

\section{Ruminal parameters and fermentation}

Ruminal fluid samples were collected about 3-4 $\mathrm{h}$ after the morning feeding on the 21 st of each period, using a rumen sampler (Geishauser, Linhart, Neidl, \& Reimann, 2012). Ruminal fluid samples were strained and sub-samples of approximately $15 \mathrm{ml}$ were performed. One of the sub-samples was acidified with $3 \mathrm{ml}$ of $50 \% \mathrm{H}_{2} \mathrm{SO}_{4}$ for $\mathrm{NH}_{3}$ analysis (Broderick \& Kang, 1980) and another sub-sample was diluted with $3 \mathrm{ml}$ of $25 \%$ metaphosphoric acid for VFA analysis (Larsen, Hansen, Weisbjerg, \& Lund, 2020) and frozen at $-20^{\circ} \mathrm{C}$ until onset analyses. 


\section{Gas production technique}

Samples of every treatment were ground in a Wiley Mill having $2 \mathrm{~mm}$ screening (Arthur H. Thomas, Philadelphia, PA, USA), and then $300 \mathrm{mg}$ were weighed into glass vials (50 ml volume). Synthetic saliva was prepared according to McDougall (1948). Ruminal contents of at least three slaughtered dairy cattle obtained from slaughter house were strained through 3-layer cheese cloth to the pre-warmed flasks leaving no headspace, rumen liquor flasks were taken to the laboratory (Lutakome et al., 2017). To form a uniform aliquot, all liquors were blended in $39^{\circ} \mathrm{C}$ under the flush of $\mathrm{CO}_{2}$ and mixed with the artificial saliva $(1: 2 \mathrm{v} / \mathrm{v})$ and loaded $(20 \mathrm{ml})$ to the glass vials. Each experimental diet sample was incubated in five replicates. Five vials of only digestion medium were used as blank vials. The vials were immediately sealed and placed in a shaker platform adjusted to $39^{\circ} \mathrm{C}$. Data for gas production of each vial were recorded after 2 , $4,6,8,12,24,36,48,72$ and 96 h of incubation using of water replacement assay (Fedorah \& Hrudey, 1983; Shirmohammadi et al., 2020). Gas production kinetic was described as the following model: $\left.y=A\left(1-e^{(-c t-l a g}\right)\right)$, where $Y$ is the volume $(\mathrm{mL})$ of produced gas at time $t$; $A$ is the gas production from the soluble and insoluble fraction $(\mathrm{mL}) ; \underline{\mathrm{c}}$ is the constant rate of gas production $\left(\mathrm{ml} \mathrm{h}^{-1}\right)$; $\mathrm{t}$ is the incubation time $(\mathrm{h})$ and lag is the lag time (h).

\section{Ex-vivo methane emission}

Along with gas production test, about $200 \mathrm{mg}$ of ground $(2 \mathrm{~mm})$ samples of each treatment were weighed into three graduated syringes (Fortune glass gas syringes $(100 \mathrm{ml})$, Fortuna Co., Germany) and prepared digestion medium were loaded ( $20 \mathrm{ml}$ ) to each syring and three syrings filled just with digestion medium as blank and placed in a shaker platform adjusted to $39^{\circ} \mathrm{C}$. After $24 \mathrm{~h}$ of incubation the cumulative gas volumes of each sample were documented and about $5 \mathrm{ml}$ of upper gas phase of each syring were sampled and injected into a gas chromatograph (GC-Clarus 500-PerkinElmer) equipped with the column (Agilent Technologies, HP-5ms GC Column, 30 $\mathrm{m}, 0.25 \mathrm{~mm}, 0.25 \mu \mathrm{m}, 7$ inch cage (CATALOG NO. 19091S-433)). The procedure run time was 65 min,samples were injected manually, initial temperature was 40 (held for $10 \mathrm{~min}$ ), then the prosedure of 10 deg per min was continued up to 290 deg which was held for $30 \mathrm{~min}$. The carrier gas was Helium (Adejoro, Hassen, Akanmu, \& Morgavi, 2020), then quantitative methane measurement were calculated by external standard.

\section{Statistical analysis}

Collected data for DMI and milk yield and composition were analyzed using PROC MIXED of SAS (SAS software version 9.4) as repeated measurement with the following model:

$$
Y_{i j k}=\mu+C_{i}+T_{j}+C T_{i j}+P_{k}+T_{j k}+e_{i j k}
$$

where $Y_{i j k}$ is the dependent variable, $\mu$ is the overall mean, $C_{i}$ is the cow, $T_{j}$ is the jth treatment (experimental diet), $\mathrm{CT}_{\mathrm{ij}}$ is the cow $\mathrm{x}$ treatment (experimental diet) interaction, $P_{k}$ is the experimental phase (phase 1 and 2), and $\mathrm{TP}_{\mathrm{jk}}$ is the treatment $\times$ phase interaction, with the error term eijk assumed to be normally distributed.

Collected data for nutrient intakes, fecal parameters, urinary and fecal $\mathrm{N}$ losses and ruminal parameters were analyzed using 
PROC GLM of SAS (SAS software version 9.4) as the following model:

$$
Y_{i j}=\mu+C_{i}+T_{j}+P_{k}+P_{j k}+e_{i j}
$$

where $Y_{i j k}$ is the dependent variable, $\mu$ is the overall mean, $\mathrm{C} i$ is the cow, $\mathrm{T}_{\mathrm{j}}$ is the $\mathrm{jth}$ treatment (experimental diet), $P_{k}$ is the experimental phase (phase 1 and 2), and $\mathrm{TP}_{\mathrm{jk}}$ is the treatment $x$ phase interaction, with the error term $e_{i j k}$ assumed to be normally distributed. P-value of $5 \%(P \leq 0.05)$ were declared as significant difference among treatments.

\section{Results and discussion}

Dry matter intake was higher for control $(P<0,01)$ than those obtained for the others (Table 2). As predicted, higher amount of $\mathrm{CP}$ was consumed by control group compared to the other groups $(P<0.01)$. We found no differences for the NDF and ADF intake among the test groups. Fecal DM and CP were not different among the test diets (Table 2), but the other fecal parameters (NDF and ADF) were differences $(P<0.05)$.

Table 2

Effect of crude protein level and rumen-protected aminoacids supplementation on nutrients intake and fecal parameters in dairy cows

\begin{tabular}{|c|c|c|c|c|c|c|c|}
\hline \multirow{2}{*}{ Item $^{2}$} & \multicolumn{5}{|c|}{ Experimental diets $^{1}$} & \multirow{2}{*}{$\mathrm{SEM}^{3}$} & \multirow{2}{*}{ P-Value } \\
\hline & Control & LM & LL & LML & LMLC & & \\
\hline \multicolumn{8}{|c|}{ Nutrient intake, kg/d } \\
\hline DM & 27.29 & 26.53 & 26.23 & 26.84 & 26.80 & 0.398 & $<.01$ \\
\hline $\mathrm{CP}$ & $4.42^{a}$ & $3.77^{b}$ & $3.72^{b}$ & $3.81^{b}$ & $3.80^{\mathrm{b}}$ & 0.057 & $<.01$ \\
\hline NDF & 8.98 & 8.68 & 8.58 & 8.78 & 8.76 & 0.130 & 0.29 \\
\hline ADF & $6.63^{a}$ & $6.37^{\mathrm{ab}}$ & $6.29^{b}$ & $6.44^{\mathrm{ab}}$ & $6.43^{\mathrm{ab}}$ & 0.096 & 0.16 \\
\hline \multicolumn{8}{|c|}{ Fecal parameters \% } \\
\hline DM & 21.52 & 21.13 & 21.68 & 20.87 & 21.35 & 0.315 & 0.41 \\
\hline $\mathrm{CP}$ & $38.22^{b}$ & $40.33^{a}$ & $40.17^{a}$ & $39.90^{\mathrm{a}}$ & $40.19^{a}$ & 0.493 & 0.09 \\
\hline NDF & 47.22 & 48.85 & 48.83 & 48.55 & 48.27 & 0.544 & 0.02 \\
\hline ADF & $33.18^{b}$ & $34.65^{\mathrm{a}}$ & $34.75^{\mathrm{a}}$ & $34.46^{\mathrm{a}}$ & $34.75^{\mathrm{a}}$ & 0.382 & 0.02 \\
\hline
\end{tabular}

Within a row, means without a common superscript letter differ $(\mathrm{P}<0.05)$.

${ }^{1}$ Control = diet containing 16.2\% CP; LM = diet containing 14.2\% CP supplemented with RPMet Mepron [Evonik Nutrition \& Care $\mathrm{GmbH}$, Hanau, Germany]; LL = diet containing 14.2\% CP supplemented with RPLys [Timet; VETAGRO S.p.A.; Reggio Emilia, Italy]; LML= diet containing 14.2\% CP supplemented with RPLys and RPMet; LMLC= diet containing 14.2\% CP supplemented with RPLys and RPMet and RPChol ReaShure (Balchem Corp., New Hampton, NY).

${ }^{2} \mathrm{DM}=$ Dry matter; $\mathrm{CP}=$ Crude protein; NDF= Nutral detergent fiber; $\mathrm{ADF}=$ Acid detergent fiber

${ }^{3} \mathrm{SEM}$ : Standard errors of mean. 
Interestingly numerically reduced $\mathrm{DMI}$, (average of $690 \mathrm{gr}$ ), an indicator of reduced CP level, differed from previous studies (Lee et al., 2011; Huhtanen \& Hetta, 2012). A depression of $1.5 \mathrm{~kg} / \mathrm{d}$ in DMl were reported by Lee et al. (2012a). Variation in the amount of reduced DMI was due to the reduced CP level percentage. in our study we decreased CP from 16.2 to 14.2 $(-12.34 \%)$ while Lee et al. (2012a) decreased CP from 15.7 to $13.6(-13.37 \%)$. Therefore both of the percentage of the reduced level and concentration of $\mathrm{CP}$ are important. In contrary, Amanlou et al. (2017) increased CP level from 16 to 19 and 21 at first 21 days after calving, they reported that DMI were increased by increasing CP concentration to 19 but no significant differences was shown between 19 and 21 levels, resulting that optimum CP level influenced DMI must be considered. Ruminal fibrolytic bacteria is influenced by RDP (Russell, O'connor, Fox, Van Soest, \& Sniffen, 1992). Reduced RDP that compensated with rumen protected AA, may decrease digestibility of the fiber in DMP diets. In our study fecal parameters such as NDF and ADF shows that fiber digestion has decreased which is in consistent with former studies (Broderick, Stevenson, Patton, Lobos, \& Colmenero, 2008; Lee et al., 2012a,b). However Noftsger et al. (2005) reported an increase in NDF and organic matter digestibilities when RPAA was used In the diet, the main differences could be the CP level where they designed to have 18.4 $\mathrm{CP}$ in the experimental diet versus $14.2 \mathrm{CP}$ of this study and the source of RPAA of this study and their study (Mepron vs. $\mathrm{HMB}$ and $\mathrm{HMBi}$ ).

Daily intake of $\mathrm{N}$ for the control was higher than those obtained for the other treatments $(P<0.01)$. Milk yield was higher for control, LML and LMLC $(P<0$.), whereas no difference was found in milk protein concentration being $3.06 \%$ on average. Calculated milk $\mathrm{N}$ for control, LML and LMLC was higher than the LL $(P<0.05)$. Urinary $\mathrm{N}$ excretion decreased significantly from $169.21 \mathrm{~g} / \mathrm{d}$ of control to $123.71 \mathrm{~g} / \mathrm{d}$ of LL $(\mathrm{P}<0.05)$. It should be noted that there were no differences among the other low protein diets, however there was an interaction effect of the experimental phase and treatment in the case of urine- $N(P<0.004)$. A significant decrease for urinary urea- $\mathrm{N}$ g/d was observed $(P=\ldots .0 .05)$ when rumen protected products were used. Urinary urea-N ratio of total urinary $\mathrm{N}$ (Table 3 ) was significantly reduced from $54.21 \%$ of control to $36.47 \%$ and $36.83 \%$ for LL and LM, respectively $(P<0.05)$. The lowest amount of fecal $N$ was for AMP while the highest was for LPDM $(P<0.01)$, whereas total excreta $N$ loss was achieved for control diet $(P<0.01)$. 
Table 3

Effect of CP level and rumen-protected aminoacids supplementation on milk production and $\mathrm{N}$ balance in dairy cows

\begin{tabular}{|c|c|c|c|c|c|c|c|}
\hline \multirow{2}{*}{ Item } & \multicolumn{5}{|c|}{ Experimental diets ${ }^{1}$} & \multirow{2}{*}{ SEM $^{2}$} & \multirow{2}{*}{ P-Value } \\
\hline & Control & LM & LL & LML & LMLC & & \\
\hline N intake, g/d & $707.34^{a}$ & $602.84^{b}$ & $595.99^{b}$ & $609.72^{b}$ & $608.91^{b}$ & 9.126 & $<.01$ \\
\hline Milk yield, kg/d & $42.90^{a}$ & $41.83^{b}$ & $41.39^{b}$ & $42.32^{\mathrm{ab}}$ & $42.34^{\mathrm{ab}}$ & 0.376 & 0.07 \\
\hline Milk protein, \% & 3.09 & 3.03 & 3.02 & 3.07 & 3.08 & 0.024 & 0.23 \\
\hline \multicolumn{8}{|c|}{$\mathrm{N}$ secretion and excretion, $\mathrm{g} / \mathrm{d}$} \\
\hline Milk N³ & $207.48^{a}$ & $198.91^{\mathrm{bc}}$ & $195.88^{c}$ & $203.92^{\mathrm{ab}}$ & $204.43^{\mathrm{ab}}$ & 2.454 & 0.01 \\
\hline Urine $\mathrm{N}^{4}$ & $169.21^{\mathrm{a}}$ & $128.43^{b}$ & $124.80^{b}$ & $123.71^{b}$ & $124.95^{b}$ & 1.877 & $<.01$ \\
\hline Urinary urea-N (UUN) & $91.70^{\mathrm{a}}$ & $47.30^{b}$ & $45.53^{b}$ & $47.75^{b}$ & $46.87^{\mathrm{b}}$ & 1.032 & $<.01$ \\
\hline UUN $\div$ total urinary $\mathrm{N}, \%$ & $54.21^{a}$ & $36.83^{\circ}$ & $36.47^{c}$ & $38.59^{b}$ & $37.50^{\mathrm{bc}}$ & 0.430 & $<.01$ \\
\hline Fecal N & $238.84^{b}$ & $252.03^{a}$ & $251.06^{a}$ & $249.38^{a}$ & $251.81^{a}$ & 3.079 & 0.02 \\
\hline Total excreta $\mathrm{N}$ & $408.06^{a}$ & $380.46^{b}$ & $375.86^{b}$ & $363.72^{b}$ & $373.09^{b}$ & 4.645 & $<.01$ \\
\hline \multicolumn{8}{|c|}{ As proportion of $\mathrm{N}$ intake, $\%$} \\
\hline Urine $\mathrm{N}$ & $23.91^{\mathrm{a}}$ & $21.31^{b}$ & $20.95^{c}$ & $20.30^{e}$ & $20.52^{d}$ & 0.064 & $<.01$ \\
\hline Fecal N & $33.79^{b}$ & $41.84^{a}$ & $42.14^{\mathrm{a}}$ & $41.00^{\mathrm{a}}$ & $41.27^{a}$ & 0.396 & $<.01$ \\
\hline Total excreta N & $57.70^{c}$ & $63.15^{\mathrm{a}}$ & $63.09^{a}$ & $61.30^{\mathrm{b}}$ & $61.79^{b}$ & 0.417 & 0.01 \\
\hline
\end{tabular}

Within a row, means without a common superscript letter differ $(P<0.05)$.

${ }^{1}$ Control $=$ diet containing $16.2 \% \mathrm{CP} ; \mathrm{LM}=$ diet containing $14.2 \% \mathrm{CP}$ supplemented with RPMet Mepron [Evonik Nutrition \& Care $\mathrm{GmbH}$, Hanau, Germany]; LL = diet containing 14.2\% CP supplemented with RPLys [Timet; VETAGRO S.p.A.; Reggio Emilia, Italy]; LML= diet containing $14.2 \%$ CP supplemented with RPLys and RPMet; LMLC= diet containing $14.2 \%$ CP supplemented with RPLys and RPMet and RPChol ReaShure (Balchem Corp., New Hampton, NY).

${ }^{2} \mathrm{SEM}$ : Standard errors of mean.

Adding both RPMet and RPLys and also RPChol resulted to the equal amount of milk production and milk $\mathrm{N}$ secretion, and also we found no differences in milk protein adding either one or both of RPAA to diets, which were consistent with that reported by Lee et al. (2012b). Similar to our results Giallongo et al. (2016) reported a reduction in milk yield when just RPMet or RPLys was used in diet as additive. Contrary to our findings Jenkins et al. (2020) reported that there is no significant difference between control and RPAA addition. A meta-analysis conducted by Huhtanen and Hristov (2009) reported that dietary $N$ intake is the primary source for determining $\mathrm{N}$ losses in dairy cattels. The amount of $\mathrm{N}$ not being retained in the animal body tissues or in its milk will be excreted in feces and urine, excreted $\mathrm{N}$ not only can contribute in water pollution and nitrogen oxides ( $\mathrm{NO}_{x}$ ) emission, but also will participate in microparticle formation of atmosphere (Hristov et al., 2019). Agriculture anthropogenic nitrous oxide $\left(\mathrm{N}_{2} \mathrm{O}\right)$, one of the major greenhouse gasees, emission is about $60 \%$ in which much of $\mathrm{N}_{2} \mathrm{O}$ is from livestock excreta that transformed as $\mathrm{N}$ deposit to soil (Hou, Velthof, \& Oenema, 2015; Hamamoto, Uchida, von Rein, \& Mukumbuta, 2020). As predicted the cows that received low protein showed a significantly less $\mathrm{N}$ due to lower 
dietary CP level. Some studies indicated a reduction in urinary $\mathrm{N}$ and urinary urea $\mathrm{N}$ (UUN) excretion when the animals received low protein diets (Lee et al., 2012a,b) which is in agreement with ours where the urine $\mathrm{N}$ and UUN have decreased on average of $25.8 \%$ and $48.9 \%$, respectively. More fecal $\mathrm{N}$ proportion of DMP diets were reported in previous studies (Lee et al., 2012a,b) being inline with the results of current study, but the most important source of ammonia emission from dairy cattle manure is the UUN, beside that the urinary $\mathrm{N}$ is responsible for about $87 \%$ of ammonia $\mathrm{N}$ effusion (Lee et al., 2011), Dijkstra, Bannink, Bosma, Lantinga, \& Reijs (2018) reported that there is a vast variation in excreted urinary $\mathrm{N}$ in comparison to fecal $\mathrm{N}$, offering opportunity for dietary manipulation to decrease urinary nitrogen excretion. resulting reducing of the $\mathrm{N}$ excreted from urine may be an effectual method to protect the environment.

No differences were observed in ruminal $\mathrm{pH}$ (Table 4), but was found an interaction between experimental phase and treatment in the case of ruminal $\mathrm{pH}(\mathrm{P}=0.04)$. As predicted, the ammonia- $\mathrm{N}$ fell significantlly
$(P<0.01)$ from $12.52 \mathrm{mg} / \mathrm{dL}$ in control diets to $11.52 \mathrm{mg} / \mathrm{dL}$ in LL diet. The highest total VFA, acetate and propionate were observed with $\mathrm{DML}$, whereas nodifferences were detected for the other VFAand the acetate to propionate ratio.

Ruminal fermentation parameters are shown in Table 4. In this study we found no significant differences in ruminal $\mathrm{pH}$, however Jenkins et al. (2020) reported a decrease in ruminal $\mathrm{pH}$ when dietary MP was high and also HMBTA (2-hydroxy-4-methylthio-butanoic acid) were used as supplementary which being due to dietary constitutes differences. In line with our results Noftsger et al. (2005) reported no changes in ruminal $\mathrm{pH}$ in the diets that contained different levels of CP. Peculiarly in the present study ruminal $\mathrm{pH}$ were above 6 while both of the aforementioned studies have reported $\mathrm{pH}$ of less than 6 . We, in this study, assumed that the amount of corn silage as percent of DM used in the diets could be the origin of this difference. we used about $20 \%$ of DM, whereas they both used around $30 \%$ of DM. 
Table 4

Effect of CP level and rumen-protected aminoacids supplementation on ruminal parameters in dairy cows

\begin{tabular}{|c|c|c|c|c|c|c|c|}
\hline \multirow{2}{*}{ Item } & \multicolumn{5}{|c|}{ Experimental diets $^{1}$} & \multirow{2}{*}{ SEM $^{2}$} & \multirow{2}{*}{ P-Value } \\
\hline & Control & LM & LL & LML & LMLC & & \\
\hline \multicolumn{8}{|l|}{ Ruminal Parameters } \\
\hline $\mathrm{pH}^{3}$ & 6.33 & 6.37 & 6.45 & 6.48 & 6.39 & 0.076 & 0.633 \\
\hline Ammonia-N (mg/dL) & $12.52^{\mathrm{a}}$ & $11.56^{b}$ & $11.52^{\mathrm{b}}$ & $11.63^{b}$ & $11.59^{b}$ & 0.099 & $<.0001$ \\
\hline Total VFA (mmol/L) & $86.51^{b}$ & $89.20^{\mathrm{ab}}$ & $87.91^{\mathrm{ab}}$ & $91.56^{\mathrm{a}}$ & $90.02^{\mathrm{ab}}$ & 1.195 & 0.045 \\
\hline Acetate, $\mathrm{mol} / 100 \mathrm{~mol}$ & $51.24^{b}$ & $52.72^{\mathrm{ab}}$ & $51.65^{b}$ & $54.02^{\mathrm{a}}$ & $53.07^{\mathrm{ab}}$ & 0.709 & 0.056 \\
\hline Propionate, $\mathrm{mol} / 100 \mathrm{~mol}$ & $22.67^{b}$ & $23.72^{\mathrm{ab}}$ & $23.53^{\mathrm{ab}}$ & $24.38^{a}$ & $23.97^{\mathrm{ab}}$ & 0.378 & 0.035 \\
\hline Butyrate, mol/100 mol & 9.98 & 10.18 & 10.04 & 10.47 & 10.30 & 0.159 & 0.212 \\
\hline Valerate, $\mathrm{mol} / 100 \mathrm{~mol}$ & 1.46 & 1.41 & 1.50 & 1.48 & 1.49 & 0.038 & 0.498 \\
\hline Isovalerate, $\mathrm{mol} / 100 \mathrm{~mol}$ & 1.16 & 1.19 & 1.19 & 1.21 & 1.19 & 0.039 & 0.881 \\
\hline Acetate: propionate & 2.26 & 2.23 & 2.20 & 2.22 & 2.22 & 0.025 & 0.514 \\
\hline
\end{tabular}

Within a row, means without a common superscript letter differ $(\mathrm{P}<0.05)$.

${ }^{1}$ Control = diet containing 16.2\% CP; LM = diet containing 14.2\% CP supplemented with RPMet Mepron [Evonik Nutrition \& Care $\mathrm{GmbH}$, Hanau, Germany]; LL = diet containing 14.2\% CP supplemented with RPLys [Timet; VETAGRO S.p.A.; Reggio Emilia, Italy]; LML= diet containing 14.2\% CP supplemented with RPLys and RPMet; LMLC= diet containing 14.2\% CP supplemented with RPLys and RPMet and RPChol ReaShure (Balchem Corp., New Hampton, NY).

2SEM: Standard errors of mean.

${ }^{3}$ experimental phase $\times$ treatment interaction $(P=0.039)$.

Ammonia-N was greater for AMP than the other experimental treatments, Sun et al. (2019) reported that decreasing RDP level can be an effective way to reduce $\mathrm{NH} 3-\mathrm{N}$, on the other hand Jenkins et al. (2020) reported that adding HMTBA in both low and high MP had tendency to increase the NH3-N pool yet they didn't conclude on the mode of action yet. it was suggested that addition of HMTBA may have stimulated the ruminal bacteria to degrade more dietry protein. Rechecking the ammonia- $\mathrm{N}$ of mentioned studies reveals that the amount of RDP can have an important role in ammonia-N pool, anyway as mentioned by an old study minimum of $5 \mathrm{mg} / \mathrm{dl}$ of ammonia-N can produce maximum ruminal bacteria (Satter \& Slyter, 1974).
Total VFA, acetate and propionate was greater for LPD groups than control group which is inline with those reported by Jenkins et al. (2020), however they found a reduction in acetate, meanwhile Noftsger et al. (2005) reported non significant differences in ruminal total VFA, acetate and propionate when $\mathrm{HMB}$, $\mathrm{HMBi}$ or DL-Met were used. Deep analysing the tables may reveal that amount of intake NDF and NFC could be suitable variables to explain the VFA component differences, in our study the amount of intake NDF was about 8.8 and Jenkins et al. (2020) was about 8.3, but for Noftsger et al. (2005) it was 5.6. On the other hand we found no differences in acetate: propionate ratio like that reported by Noftsger et al. (2005), while Jenkins et al. (2020) reported a decrease in the later parameter, which can 
be as a result of NFC fermentation, where our diets NFC was 43 which is similar to that of Noftsger et al. (2005).

Although did significant, the initial incubation times of gas production were numerically higher for LMLC (Table 5), but from $8 \mathrm{~h}$ of incubation the gas production changed up to the last times of incubation (120 h) where the control diet had the numerically highest value $(334.40 \mathrm{ml} / \mathrm{g}$ of $\mathrm{DM}$ ) and the $\mathrm{LL}$ diet showed the lowest concentration $(327.84 \mathrm{ml} /$ gDM). Total gas production at $24 \mathrm{~h}$ (Lit/d DM) was higher for control, LML and LMLC than the other two diets (Table 6). The potential of gas production $(A, \mathrm{ml} / \mathrm{g} D M)$, constant rate of gas production $\left(c, h^{-1}\right)$ and lag phase were not different between treatments. Ex-vivo methane emission of diets ( $\mathrm{ml} / \mathrm{g}$ DM) was not different, but the variation in DMl between treatments caused the significant difference for methane emissions, whereas these values in control and LML were more than the others $(P<0.05)$.

\section{Table 5}

Effect of CP level and rumen-protected (RP) AA supplementation on cumulative gas production and methane emission ( $\mathrm{ml} / \mathrm{gr} \mathrm{DM})$ in dairy cows

\begin{tabular}{|c|c|c|c|c|c|c|c|}
\hline \multirow{2}{*}{ Hours } & \multicolumn{5}{|c|}{ Experimental diets ${ }^{1}$} & \multirow{2}{*}{ SEM $^{2}$} & \multirow{2}{*}{ P-Value } \\
\hline & Control & LM & LL & LML & LMLC & & \\
\hline 2 & 74.96 & 74.16 & 78.76 & 78.16 & 79.56 & 2.27 & 0.37 \\
\hline 4 & 117.68 & 115.28 & 118.48 & 118.88 & 120.68 & 2.57 & 0.67 \\
\hline 6 & 153.64 & 149.24 & 153.24 & 152.44 & 154.44 & 2.9 & 0.75 \\
\hline 8 & 186.52 & 181.32 & 184.92 & 183.52 & 184.52 & 3.33 & 0.85 \\
\hline 12 & 224.32 & 218.52 & 223.12 & 221.32 & 221.92 & 3.56 & 0.82 \\
\hline 24 & 275.56 & 268.16 & 271.36 & 270.96 & 269.36 & 4.34 & 0.79 \\
\hline 48 & 302.08 & 295.68 & 298.08 & 299.48 & 294.28 & 4.53 & 0.76 \\
\hline 72 & 321.76 & 316.36 & 318.36 & 320.56 & 315.96 & 4.27 & 0.83 \\
\hline 96 & 330 & 325.36 & 325.16 & 327.16 & 324.76 & 4.54 & 0.92 \\
\hline 120 & 334.4 & 328.16 & 327.84 & 329.44 & 328.04 & 4.67 & 0.84 \\
\hline
\end{tabular}

Within a column, means without a common superscript letter differ $(P<0.05)$.

$n=25 ; n$ represents number of observations used in the statistical analysis.

${ }^{1}$ Control $=$ diet containing 16.2\% CP; LM = diet containing 14.2\% CP supplemented with RPMet Mepron [Evonik Nutrition \& Care $\mathrm{GmbH}$, Hanau, Germany]; LL = diet containing 14.2\% CP supplemented with RPLys [Timet; VETAGRO S.p.A.; Reggio Emilia, Italy]; LML= diet containing 14.2\% CP supplemented with RPLys and RPMet; LMLC= diet containing 14.2\% CP supplemented with RPLys and RPMet and RPChol ReaShure (Balchem Corp., New Hampton, NY).

2SEM: Standard errors of mean. 
Table 6

Effect of CP level and rumen-protected (RP) AA supplementation on ruminal gas production paramaters and methane emission in dairy cows

\begin{tabular}{|c|c|c|c|c|c|c|c|}
\hline \multirow{2}{*}{ Item } & \multicolumn{5}{|c|}{ Experimental diets $^{1}$} & \multirow{2}{*}{ SEM $^{2}$} & \multirow{2}{*}{ P-Value } \\
\hline & Control & LM & LL & LML & LMLC & & \\
\hline \multicolumn{8}{|l|}{ Ruminal Gas production parameters } \\
\hline Total gas production in $24 \mathrm{~h}$, Lit/d DM & $7520.0^{a}$ & $7114.3^{b}$ & $7117.8^{b}$ & $7272.6^{\mathrm{ab}}$ & $7218.9^{a b}$ & 116.52 & 0.129 \\
\hline $\mathrm{A}^{3}, \mathrm{ml} / \mathrm{g} \mathrm{DM}$ & 292.95 & 285.64 & 288.80 & 289.05 & 285.50 & 5.150 & 0.839 \\
\hline$c^{4}, h^{-1}$ & 0.117 & 0.115 & 0.115 & 0.114 & 0.117 & 0.003 & 0.906 \\
\hline $\operatorname{Lag}^{5}, \mathrm{~h}$ & 0.485 & 0.578 & 0.695 & 0.739 & 0.755 & 0.087 & 0.183 \\
\hline \multicolumn{8}{|l|}{ Methane emission } \\
\hline $\mathrm{CH}_{4}$ production in $24 \mathrm{~h}, \mathrm{ml} / \mathrm{g} \mathrm{DM}$ & 22.05 & 21.18 & 21.44 & 21.57 & 21.25 & 0.345 & 0.440 \\
\hline $\mathrm{CH}_{4}$ production in $24 \mathrm{~h}$, Lit/d DM & $601.6^{a}$ & $562.03^{b}$ & $562.3^{b}$ & $578.9^{\mathrm{ab}}$ & $569.6^{b}$ & 9.258 & 0.037 \\
\hline
\end{tabular}

Within a row, means without a common superscript letter differ $(P<0.05)$.

${ }^{1}$ Control $=$ diet containing $16.2 \% \mathrm{CP} ; \mathrm{LM}=$ diet containing $14.2 \% \mathrm{CP}$ supplemented with RPMet Mepron [Evonik Nutrition \& Care $\mathrm{GmbH}$, Hanau, Germany]; LL = diet containing $14.2 \%$ CP supplemented with RPLys [Timet; VETAGRO S.p.A.; Reggio Emilia, Italy]; LML= diet containing $14.2 \%$ CP supplemented with RPLys and RPMet; LMLC= diet containing $14.2 \%$ CP supplemented with RPLys and RPMet and RPChol ReaShure (Balchem Corp., New Hampton, NY).

${ }^{2} \mathrm{SEM}$ : Standard errors of mean.

${ }^{3} \mathrm{~A}=$ asymptotic gas production (ml/g DM incubated);

${ }^{4} \mathrm{C}=$ fractional rate of fermentation $3(\mathrm{~h}-1)$;

${ }^{5} \mathrm{Lag}=$ lag time $(\mathrm{h})$.

Fermentable energy, being a considerable energy source for ruminants, is produced from the breakdown of lignocellulosic material by ruminal microbiome enzymes as well as gas production resulted through fermentation of carbohydrate substances (Solden et al., 2018; Stewart et al., 2018). Our results of gas production showed no significant differences among the test diets. The amount of most effective materials in gas production may include NDF, ADF, NFC and $C P$. The NDF and ADF were in equal amounts in experimental diets, whereas numerically the NFC and CP were higher and lower in low protein, respectively. We assumed that because the $\mathrm{N}-\mathrm{NH} 3$ of the diets could prepare suitable amount of $\mathrm{N}$ for microorganisms growth, therefore apart from the carbohydrate structure presented in CP-source feed stuffs the $\mathrm{N}$ part has less influence in gas production. On the other hand, the mentioned carbohydrate structure maybe has been able to compensate for the deficiency of about $1.7 \%$ of NFC in the control diet, resulted in the equal volume of cumulative gas production.

As it has been shown in Table 6 no significant differenceswere detected in ruminal gas production parameters. In the rumen, an anaerobic chamber, bacteria attach to the cut edge of feed stuff to develop their colonies, this attachment needs time which is called lag phase. Lag phase was similar in experimental diets defining that the gas production started in the similar time in the rumen, however lag phase was numerically less for the control diet compared to low protein diets. Gas production parameters $A(\mathrm{ml} / \mathrm{g} \mathrm{DM})$ and $\mathrm{c}\left(\mathrm{ml} \mathrm{h}^{-1}\right)$ didn't 
differ among the diets showing that diets with reduced $\mathrm{CP}$ may have the similar kinetics of digestion and gas production, but the scenario of gas production is not limited to simply one gram of DM, the DMI plays an important role in gas production volume and methane emission (Hristov \& Melgar, 2020). Where the total gas production of $24 \mathrm{~h}$ based on DMI were higher for control, LML and LMLC.

Molecular hydrogen and $\mathrm{CO}_{2}$ are main substances for ruminal methanogen bacteria to produce methane, $\mathrm{H} 2$ can be produced through fermentation of carbohydrates when butyrate and acetate is produced, too (Moss, Jouany, \& Newbold, 2000). Although Acetate level was increased in DMP diets, nevertheless we found no significant differences in $\mathrm{CH} 4$ production in $1 \mathrm{gr}$ of DM of test diets. Beside the acetate and butyrate as methane promoter pathways, propionate production is assumed as an opponent (Moss et al., 2000). We found that the propionate was increased in the low protein like acetate, therefore referring to acetate: propionate ratio which was not significant among the experimental diets explaining the insignificancy of methane production. Our results agreed with those reported by Hynes et al. (2016), they reduced CP level from 18.1 to 14.1 but no significant difference in methane emission was obtained, however they have used fresh-cut grass beside the reduced level of concentrate CP. But discussing in the volume of methane production when DMI is included revealed that control diet produced much more methane than the other low protein $(P<0.05)$. It was concluded that gas production values and methane emission in the farm level is not only depended on diet but also the DMI plays an important role.

\section{Conclusions}

We didn't detect any significant difference in DMI with RPAA supplementation to a dairy cattle diet being deficient in MP. Fecal parameters induced a reduction in $\mathrm{CP}$ and ADF digestibility in DMP diets. Adding both RPAA or with RPcholine compensated MP deficient in milk yield and protein. Nitrogen excretion as urinary $\mathrm{N}$ and total excreta $\mathrm{N}$ was significantly decreased which reduces loaded $\mathrm{N}$ to the environment. Ruminal $\mathrm{pH}$ and acetate: propionate ratio did not differ among test diets, but the ruminal ammonia- $\mathrm{N}$ decreased with test diets. Calculated cumulative gas production and methane emission in the farm level decreased significantly among test diets. Our findings indicated that reducing the $\mathrm{N}$ intake can be compensated by adding RPAA not only to keep the animal performance but also decreasing the environmental contamination by nitrogen and methane as greenhouse gases.

\section{Acknowledgements}

The authors are thankful to the staff of Advanced Animal Nutrition Laboratory, KhalatPooshan Research Center of University of Tabriz and Samimi industrial dairy farm.

\section{References}

Adejoro, F. A., Hassen, A., Akanmu, A. M., \& Morgavi, D. P. (2020). Replacing urea with nitrate as a non-protein nitrogen source increases lambs' growth and reduces methane production, whereas acacia tannin has no effect. Animal Feed Science and Technology, 259, 114360. doi: 10.10 16/j.anifeedsci.2019.114360 
Amanlou, H., Farahani, T. A., \& Farsuni, N. E. (2017). Effects of rumen undegradable protein supplementation on productive performance and indicators of protein and energy metabolism in Holstein fresh cows. Journal of Dairy Science, 100(5), 36283640. doi: 10.3168/jds.2016-11794

AOAC. (2005). AOAC international guidelines for laboratories performing microbiological and chemical analyses of food and pharmaceuticals: An aid to interpretation of ISO/IEC 17025. Rockville, MD: AOAC International.

Broderick, G., \& Kang, J. (1980). Automated simultaneous determination of ammonia and total amino acids in ruminal fluid and in vitro media. Journal of Dairy Science, 63(1), 64-75. doi: 10.3168/jds.S0022-03 02(80)82888-8

Broderick, G., Stevenson, M., Patton, R., Lobos, N., \& Colmenero, J. O. (2008). Effect of supplementing rumen-protected methionine on production and nitrogen excretion in lactating dairy cows. Journal of Dairy Science, 91(3), 1092-1102. doi: 10.3168/jds.2007-0769

Buddle, B. M., Denis, M., Attwood, G. T., Altermann, E., Janssen, P. H., Ronimus, R. S.,... Wedlock, D. N. (2011). Strategies to reduce methane emissions from farmed ruminants grazing on pasture. The Veterinary Journal, 188(1), 11-17. doi: 10.1016/j.tvjl.2010.02.019

Dijkstra, J., Bannink, A., Bosma, P. M., Lantinga, E. A., \& Reijs, J. W. (2018). Modeling the effect of nutritional strategies for dairy cows on the composition of excreta nitrogen. Frontiers in Sustainable Food Systems, 2, 63. doi: $10.3389 /$ fsufs. 2018.00063

Fedorah, P. M., \& Hrudey, S. E. (1983). A simple apparatus for measuring gas production by methanogenic cultures in serum bottles. Environmental Technology, 4(10), 425432. doi: 10.1080/09593338309384228

Geishauser, T., Linhart, N., Neidl, A., \& Reimann, A. (2012). Factors associated with ruminal $\mathrm{pH}$ at herd level. Journal of Dairy Science, 95(8), 4556-4567. doi: 10.3168/jds.20125380

Giallongo, F., Harper, M., Oh, J., Lopes, J., Lapierre, H., Patton, R.,... Hristov, A. N. (2016). Effects of rumen-protected methionine, lysine, and histidine on lactation performance of dairy cows. Journal of Dairy Science, 99(6), 44374452. doi: 10.3168/jds.2015-10822

Gill, M., Smith, P., \& Wilkinson, J. (2010). Mitigating climate change: the role of domestic livestock. Animal, 4(3), 323-333. doi: $10.1017 / S 1751731109004662$

Gomez, A., Mendoza, G. D., Garcìa-Bojalil, C., Barcena, R., Ramos, J. A., Crosby, M. M.,... Lara, A. (2011). Effect of supplementation with urea, blood meal, and rumenprotected methionine on growth performance of Holstein heifers grazing kikuyu pasture. Tropical Animal Health and Production, 43(3), 721-724. doi: 10.1007/ s11250-010-9759-z

Greening, C., Geier, R., Wang, C., Woods, L. C., Morales, S. E., McDonald, M. J.,... Leahy, S. C. (2019). Diverse hydrogen production and consumption pathways influence methane production in ruminants. The ISME Journal, 13, 2617-2632. doi: 10.10 38/s41396-019-0464-2

Hamamoto, T., Uchida, Y., von Rein, I., \& Mukumbuta, I. (2020). Effects of short-term freezing on nitrous oxide emissions and enzyme activities in a grazed pasture soil after bovine-urine application. Science of the Total Environment, (740), 140006. doi: 10.1016/j.scitotenv.2020.140006 
Henderson, G., Cook, G. M., \& Ronimus, R. S. (2018). Enzyme-and gene-based approaches for developing methanogenspecific compounds to control ruminant methane emissions: a review. Animal Production Science, 58(6), 1017-1026. doi: 10.1071/AN15757

Henderson, G., Cox, F., Ganesh, S., Jonker, A., Young, W., Collaborators, G. R. C.,... Arenas, G. N. (2015). Rumen microbial community composition varies with diet and host, but a core microbiome is found across a wide geographical range. Scientific Reports, 5(1), 14567. doi: 10.1038/srep14567

Hou, Y., Velthof, G. L., \& Oenema, O. (2015). Mitigation of ammonia, nitrous oxide and methane emissions from manure management chains: a meta-analysis and integrated assessment. Global Change Biology, 21(3), 1293-1312. doi: 10.1111/ gcb. 12767

Hristov, A. N., \& Melgar, A. (2020). Relationship of dry matter intake with enteric methane emission measured with the GreenFeed system in dairy cows receiving a diet without or with 3-nitrooxypropanol. Animal, 14(S3), s484-s490. doi: 10.1017/ S1751731120001731

Hristov, A. N., Bannink, A., Crompton, L. A., Huhtanen, P., Kreuzer, M., McGee, M.,... Yáñez-Ruiz, D. R. (2019). Invited review: nitrogen in ruminant nutrition: a review of measurement techniques. Journal of Dairy Science, 102(7), 5811-5852. doi: 10.3168/jds.2018-15829

Hristov, A. N., Oh, J., Giallongo, F., Frederick, T. W., Harper, M. T., Weeks, H. L.,... Williams, S. R. O. (2015). An inhibitor persistently decreased enteric methane emission from dairy cows with no negative effect on milk production. Proceedings of the National Academy of Sciences, 112(34), 1066310668. doi: $10.1073 /$ pnas. 1504124112
Huhtanen, P., \& Hetta, M. (2012). Comparison of feed intake and milk production responses in continuous and changeover design dairy cow experiments. Livestock Science, 143(2-3), 184-194. doi: 10.1016/j. livsci.2011.09.012

Huhtanen, P., \& Hristov, A. N. (2009). A metaanalysis of the effects of dietary protein concentration and degradability on milk protein yield and milk $\mathrm{N}$ efficiency in dairy cows. Journal of Dairy Science, 92(7), 3222-3232. doi: 10.3168/jds.2008-1352

Hynes, D. N., Stergiadis, S., Gordon, A., \& Yan, T. (2016). Effects of concentrate crude protein content on nutrient digestibility, energy utilization, and methane emissions in lactating dairy cows fed fresh-cut perennial grass. Journal of Dairy Science, 99(11), 8858-8866. doi: 10.3168/jds.201611509.

I.C.o.A.C. (1995). Guide to the care and use of experimental animals. Isfahan, Iran: Isfahan University of Technology Isfahan.

Jarrell, K. F., \& Kalmokoff, M. L. (1988). Nutritional requirements of the methanogenic archaebacteria. Canadian Journal of Microbiology, 34(5), 557-576. doi: 10.1139/m88-095

Jenkins, C., Fernando, S., Anderson, C., Aluthge, N., Castillo-Lopez, E., Zanton, G., \& Kononoff, P. (2020). The effects of 2-hydroxy-4-methylthio-butanoic acid supplementation on the rumen microbial population and duodenal flow of microbial nitrogen. Journal of Dairy Science, 103(11), 10161-10174. doi: 10.3168/jds. 2019-17664

Johnson, K. A., \& Johnson, D. E. (1995). Methane emissions from cattle. Journal of Animal Science, 73(8), 2483-2492. doi: $10.2527 / 1995.7382483 x$ 
Kalscheur, K., Vi, R. B., Glenn, B., \& Kohn, R. (2006). Milk production of dairy cows fed differing concentrations of rumendegraded protein. Journal of Dairy Science, 89(1), 249-259. doi: 10.3168/jds. S0022-0302(06)72089-6

Kelly, W. J., Leahy, S. C., Li, D., Perry, R., Lambie, S. C., Attwood, G. T., \& Altermann, E. (2014). The complete genome sequence of the rumen methanogen Methanobacterium formicicum BRM9. Standards in Genomic Sciences, 9(1), 15. doi: 10.1186/1944-32 77-9-15

Kiggundu, M., Nantongo, Z., Kayondo, S. I., \& Mugerwa, S. (2019). Enteric methane emissions of grazing short-horn zebu weaner bulls vary with estimation method and level of crude protein supplementation. Tropical Animal Health and Production, 52, 1269-1276. doi: 10.1007/s11250-019-02 127-2.

Lambie, S. C., Kelly, W. J., Leahy, S. C., Li, D., Reilly, K., McAllister, T. A.,... Altermann, E. (2015). The complete genome sequence of the rumen methanogen Methanosarcina barkeri CM1. Standards in Genomic Sciences, 10(1), 57. doi: 10.1186/s40793015-0038-5

Larsen, M., Hansen, N. P., Weisbjerg, M. R., \& Lund, P. (2020). Evaluation of the ororuminal FLORA sampling device for rumen fluid sampling in intact cattle. Journal of Dairy Science, 103(1), 447-450. doi: 10.3168/jds.2019-16972

Leahy, S. C., Kelly, W. J., Altermann, E., Ronimus, R. S., Yeoman, C. J., Pacheco, D. M.,... Sang, C. (2010). The genome sequence of the rumen methanogen Methanobrevibacter ruminantium reveals new possibilities for controlling ruminant methane emissions. PloS one, 5(1), e8926. doi: 10.1371/journal. pone.0008926
Lee, C., Hristov, A. N., Cassidy, T., Heyler, K., Lapierre, H., Varga, G.,... Parys, C. (2012a). Rumen-protected lysine, methionine, and histidine increase milk protein yield in dairy cows fed a metabolizable proteindeficient diet. Journal of Dairy Science, 95(10), 6042-6056. doi: 10.3168/jds.20125581

Lee, C., Hristov, A. N., Heyler, K., Cassidy, T., Lapierre, H., Varga, G., \& Parys, C. (2012b). Effects of metabolizable protein supply and amino acid supplementation on nitrogen utilization, milk production, and ammonia emissions from manure in dairy cows. Journal of Dairy Science, 95(9), 5253-5268. doi: 10. 3168/jds.2012-5366

Lee, C., Hristov, A. N., Heyler, K., Cassidy, T., Long, M., Corl, B., \& Karnati, S. (2011). Effects of dietary protein concentration and coconut oil supplementation on nitrogen utilization and production in dairy cows. Journal of Dairy Science, 94(11), 5544-5557. doi: 10.3168/jds.2010-3889

Li, Y., Leahy, S. C., Jeyanathan, J., Henderson, G., Cox, F., Altermann, E.,.. Rakonjac, J. (2016). The complete genome sequence of the methanogenic archaeon ISO4-H5 provides insights into the methylotrophic lifestyle of a ruminal representative of the Methanomassiliicoccales. Standards in Genomic Sciences, 11(1), 59. doi: 10.1186/ s40793-016-0183-5

Lutakome, P., Kabi, F., Tibayungwa, F., Laswai, G. H., Kimambo, A., \& Ebong, C. (2017). Rumen liquor from slaughtered cattle as inoculum for feed evaluation. Animal Nutrition, 3(3), 300-308. doi: 10.1016/j. aninu.2017.06.010

Martin, C., Morgavi, D., \& Doreau, M. (2010). Methane mitigation in ruminants: from microbeto the farm scale. Animal, 4(3), 351365. doi: $10.1017 / S 1751731109990620$ 
McDougall, E. (1948). Studies on ruminant saliva. 1. The composition and output of sheep's saliva. Biochemical Journal, 43(1), 99. doi: 10.1042/bj0430099

Moss, A. R., Jouany, J.-P., \& Newbold, J. (2000). Methane production by ruminants: its contribution to global warming. Annales de Zootechnie, 49(2000) 231-253. doi: 10. 1051/animres:2000119.

National Research Council (2001). Nutrient requirements of dairy cattle (7nd rev. ed.). Washington, DC: National Academy Press.

Noftsger, S., St-Pierre, N., \& Sylvester, J. (2005). Determination of rumen degradability and ruminal effects of three sources of methionine in lactating cows. Journal of Dairy Science, 88(1), 223-237. doi: 10. 3168/ jds.S0022-0302(05)72680-1

Rehman, A., Arif, M., Saeed, M., Manan, A., AlSagheer, A., El-Hack, M. E.,... Alowaimer, A. N. (2020). Nutrient digestibility, nitrogen excretion, and milk production of midlactation Jersey $\times$ Friesian cows fed diets containing different proportions of rumenundegradable protein. Anais da Academia Brasileira de Ciências, 92(Suppl. 1), 1-13. doi: 10.1590/0001-3765202020180787

Russell, J. B., O'connor, J., Fox, D., Van Soest, P., \& Sniffen, C. (1992). A net carbohydrate and protein system for evaluating cattle diets: I. Ruminal fermentation. Journal of Animal Science, 70(11), 3551-3561. doi: 10.2527/1992.70113551x

Satter, L., \& Slyter, L. (1974). Effect of ammonia concentration on rumen microbial protein production in vitro. British Journal of Nutrition, 32(2), 199-208. doi: 10.1079/ BJN19740073

Serrano, R. D. C., Cruz, O. T. B., Coneglian, S. M., \& Branco, A. F. (2020). Use of cashew and castor essential oils to improve fibre digestibility in high forage diets: digestibility, ruminal fermentation and microbial protein synthesis. Semina: Ciências Agrárias, 41(6, Suppl. 2), 34293440. doi: 10.5433/1679-0359.2020v41 n6Supl2p3429

Seshadri, R., Leahy, S. C., Attwood, G. T., Teh, K. H., Lambie, S. C., Cookson, A. L.,... Varghese, N. J. (2018). Cultivation and sequencing of rumen microbiome members from the Hungate1000 Collection. Nature Biotechnology, 36(4), 359. doi: 10.1038/ nbt.4110

Shirmohammadi, S., Taghizadeh, A., Hosseinkhani, A., Moghaddam, G. A., Salem, A. Z., \& Pliego, A. B. (2020). Ruminal and post-ruminal barley grain digestion and starch granule morphology under three heat methods. Annals of Applied Biology, 178(3), 508-518. doi: 10.1111/ aab.12662

Solden, L. M., Naas, A. E., Roux, S., Daly, R. A., Collins, W. B., Nicora, C. D.,... Jørgensen, B. (2018). Interspecies cross-feeding orchestrates carbon degradation in the rumen ecosystem. Nature Microbiology, 3(11), 1274. doi: 10.1038/s41564-0180225-4

Stewart, R. D., Auffret, M. D., Warr, A., Wiser, A. H., Press, M. O., Langford, K. W.,... Walker, A. W. (2018). Assembly of 913 microbial genomes from metagenomic sequencing of the cow rumen. Nature Communications, 9(1), 870. doi: 10.1038/ s41467-018-03317-6

Sun, F., Aguerre, M., \& Wattiaux, M. (2019). Starch and dextrose at 2 levels of rumendegradable protein in iso-nitrogenous diets: Effects on lactation performance, ruminal measurements, methane emission, digestibility, and nitrogen balance of dairy cows. Journal of Dairy Science, 102(2), 1281-1293. doi: 10.3168/ jds.2018-15041 
Swanepoel, N., Robinson, P., \& Erasmus, L. (2010). Amino acid needs of lactating dairy cows: impact of feeding lysine in a ruminally protected form on productivity of lactating dairy cows. Animal Feed Science and Technology, 157(1-2), 79-94. doi: 10.1016/j.anifeedsci.2010.02.008.

Thauer, R. K. (2012). The wolfe cycle comes full circle. Proceedings of the National Academy of Sciences, 109(38), 1508415085. doi: 10.1073/pnas.1213193109

Valadares, R., Broderick, G., Valadares, S., Fo., \& Clayton, M. (1999). Effect of replacing alfalfa silage with high moisture corn on ruminal protein synthesis estimated from excretion of total purine derivatives. Journal of Dairy Science, 82(12), 26862696. doi: 10.3168/jds.S0022-0302(99) 75525-6

van Lingen, H. J., Jonker, A., Kebreab, E., \& Pacheco, D. (2021). Quantitative joint evaluation of sheep enteric methane emissions and faecal dry matter and nitrogen excretion. Agriculture, Ecosystems \& Environment, 305, 107116. doi: 10.1016/j.agee.2020.107116

Van Soest, P. V., Robertson, J., \& Lewis, B. (1991). Methods for dietary fiber, neutral detergent fiber, and nonstarch polysaccharides in relation to animal nutrition. Journal of Dairy Science, 74(10), 3583-3597. doi: 10.3168/jds.S0022-0302 (91)78551-2
Van Zanten, H., Meerburg, B., Bikker, P., Herrero, M., \& De Boer, I. (2016). Opinion paper: the role of livestock in a sustainable diet: a land-use perspective. Animal, 10(4), 547549. doi: 10.1017/S1751731115002694

Wedlock, D., Janssen, P., Leahy, S., Shu, D., \& Buddle, B. (2013). Progress in the development of vaccines against rumen methanogens. Animal, 7(Suppl. 2), 244252. doi: $10.1017 / S 1751731113000682$

Weimar, M., Cheung, J., Dey, D., McSweeney, C., Morrison, M., Kobayashi, Y.,... Ronimus, R. (2017). Development of multiwellplate methods using pure cultures of methanogens to identify new inhibitors for suppressing ruminant methane emissions. Applied and Environmental Microbiology, 83(15), e00396-00317. doi: 10.1128/AEM.00396-17

Wu, P., Liu, Z., He, W., Yu, S., Gao, G., \& Wang, J. (2018). Intermittent feeding of citrus essential oils as a potential strategy to decrease methane production by reducing microbial adaptation. Journal of Cleaner Production, 194, 704-713. doi: 10.1016/j. jclepro.2018.05.167

Zenobi, M., Gardinal, R., Zuniga, J., Dias, A., Nelson, C., Driver, J.,... Staples, C. (2018). Effects of supplementation with ruminally protected choline on performance of multiparous Holstein cows did not depend upon prepartum caloric intake. Journal of Dairy Science, 101(2), 1088-1110. doi: 10.3168/jds.2017-13327 